\title{
Persisting Beaux-Arts Practices in Architectural Education: History and Theory Teaching at the Auckland School of Architecture, 1927-1969
}

\begin{abstract}
"Dis-moi ce que tu lis, je te dirai qui tu es," il est vrai, mais je te connaîtrai mieux si tu me dis ce que tu relis. (Mauriac 1959: 138)

[“Tell me what you read and I'll tell you who you are," is true enough, but I would know you better if you told me what you re-read].
\end{abstract}

In architectural history, it is easy to focus on buildings and structures and, in doing so, to overlook the influence of the written word on architectural development-for various and, one might add, obvious reasons. The significance of the great treatises-from Vitruvius' De Architectura to Le Corbusier's Vers une Architecture-is acknowledged and widely discussed in architectural scholarship. But what about the numerous, less famous titles, subtly making their contribution to the course of architectural history? Literature has played a particularly important part in the history of institutionalised architectural education. It rose to prominence within the Beaux-Arts tradition. The academic intellectual climate of the French school nurtured the specific profile of the architects. Beaux-Arts students were well-trained academics, encouraged to assume the role of a scholar in the exploration of the past. The achievements of architectural history were condensed in treatises on composition, proportion, symmetry, ornamentation, etc. Books became a supplement to, or, in countries remote from Europe, a substitute for actual buildings. Furthermore, a tendency to perceive every historical phenomenon as a unique structure shaped by specific sets of conditions gained in strength since its emergence in the eighteenth century. The architectural past was no exception. To fully understand the architectural production of different époques and environments, architects needed to study the broader socio-economic, political, and cultural context. Historiography was their strongest ally.

The Beaux-Arts methods were systematically introduced into the Auckland School of Architecture by Professor Cyril Knight, the first Professor of Architecture, who took up his position in 1925 (Treep 2017: 25-31). Knight was living in New York at the time of his appointment and his first task was to purchase books for the architecture library. The telegram Knight received informing him about his professorship included $£ 100$ for this purpose. Unfortunately, the list of the titles Knight brought from New York has been lost. However, it is possible to 
learn which books were deemed necessary for the education of architects from the School's annual Prospectus. These publications present valuable information about the Auckland School, including the reading lists for individual courses, or papers. There can be no doubt that the teachers sometimes deviated from the officially advertised content. They would have offered their personal interpretations, decided the extent to which individual books were to be used, and suggested other titles to their students. Nonetheless, the official School prospectuses documented the institutionalised intellectual climate that influenced the formal education of young architects in Auckland for decades (see Fig. 1).

The words by the influential French writer François Mauriac were an appropriate line of inspiration for this article. Exploring the titles students were-at least officially-encouraged to read and re-read, the article is focused on the teaching of history and theory at the Auckland School of Architecture. History and theory courses formed the conceptual nucleus of the curriculum in the educational tradition of the Beaux-Arts. In turn, knowledge and comprehension of the architectural past informed the teaching of design and drawing. However, a curious

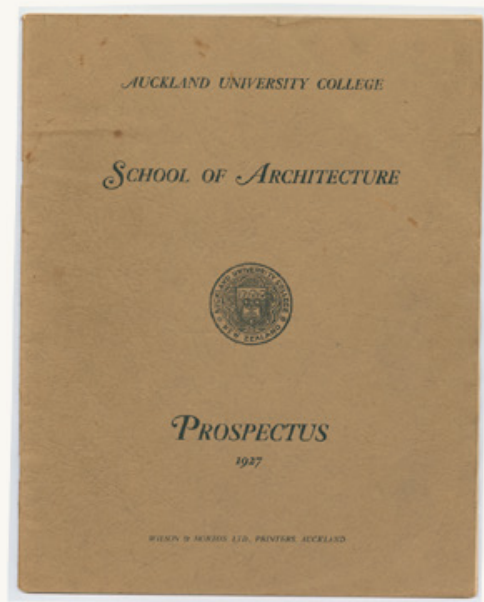

A.

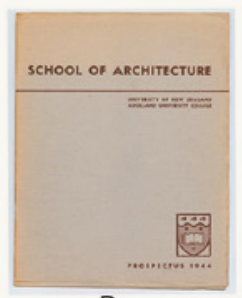

B.

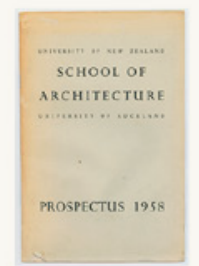

D.

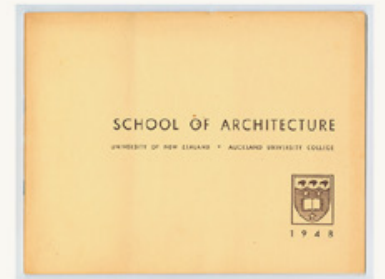

C.

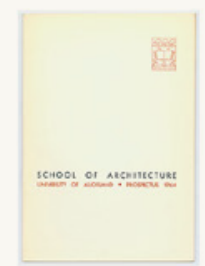

E.

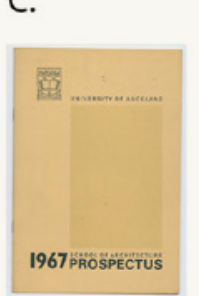

F.

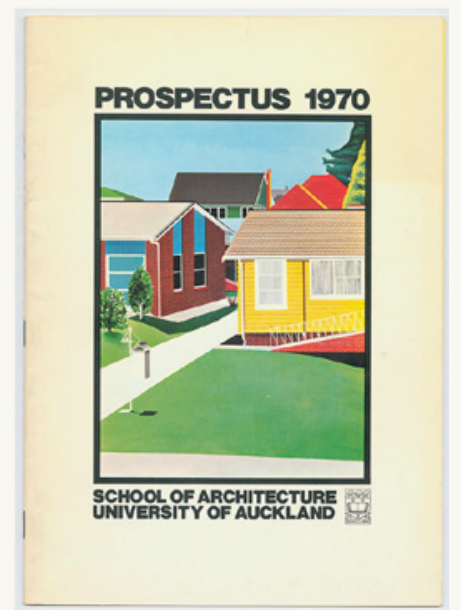

G.
Fig. 1 In the period covered by this article, the Auckland School of Architecture Prospectus was redesigned six times. Above are the cover pages for the years 1927 (a), 1944 (b), 1948 (c), 1958 (d), 1964 (e), 1967 (f), and 1970 (g). dichotomy developed at the Auckland School. On one hand, the residues of a conservative Beaux-Art tradition were apparent in the recommended bibliography and descriptions of history and theory courses until as late as 1969. On the other, from the 1930s on, student designs were obviously influenced by modernist ideas. Tracing the gradual transformation of the history and theory courses from 1927 to 1969, the article explores the persistence of Beaux-Arts influences at the School, and, consequently, demonstrates that the once resounding ideas of the École des Beaux-Arts had echoes, even if increasingly faint, until well into the twentieth century. 


\section{"The World-Famous System": École des Beaux-Arts as the Model for New Zealand}

The early history of architectural education in New Zealand has been discussed by Ann McEwan $(1999,2001)$ and Lucy Treep $(2017)$. McEwan $(1999,2001)$ has shown that in New Zealand, as in Britain and the United States, the study of architecture existed for decades outside of the university context, prior to becoming a taught discipline. Aspiring candidates could learn their craft in the office of a senior architect, by correspondence or-for the few who could afford it-studying at an overseas university. However, the prosperous years of the early twentieth century instigated changes in New Zealand's architectural profession. The economy was recovering from the previous decades of crisis, and the colony became a dominion in 1907. In an atmosphere of growing national pride and general prosperity, confidence in the future of the architectural profession gained strength. The New Zealand Institute of Architects (NZIA) was established in 1905, and a three-year Diploma Course in Architecture was offered by Canterbury College from 1914, run in conjunction with the Schools of Art and Engineering. Determined to raise the profession to a more advanced level, architects campaigned for the establishment of an architectural school in New Zealand. After years of debate, the relentless efforts of the NZIA and individual practitioners ultimately bore fruit. The first New Zealand School of Architecture was officially established at Auckland University College in 1917.

One hundred years later, in the School's centennial history, Treep (2017) reveals the important role that Professor Knight played in the employment of Beaux-Arts methods during the early history of the Auckland School. His formal education and professional experiences were deeply rooted in the French tradition. Of Australian origin, Knight graduated with a first-class honours degree in architecture from the University of Liverpool. He broadened his understanding of the discipline through architectural studies in Europe-mostly Paris-and the United States. Lacking systematised architectural education, the United States and the United Kingdom adopted the Beaux-Arts model for the development of their tertiary-level instruction during the course of the nineteenth century. In both countries, architectural knowledge was previously acquired through the traditional system of apprenticeship. In contrast, the École des Beaux-Arts in Paris developed a centralised, government-funded, and systematic education from the middle of the seventeenth century (Drexler 1977; Egbert \& Van Zanten ca. 1980). The United States employed the Beaux-Arts model for the first time at MIT in 1865 (Draper 1977; Noffsinger 1955). England got its first full-time architectural programme in 1895, again based on the Beaux-Arts system, at the University of Liverpool (Crouch 2002). Both the British and the American schools taught the Beaux-Arts design principles and, especially at first, aimed to employ French design tutors. However, they did not copy the programme of the École des Beaux-Arts-rather, the content taught at the French school was adapted to fit university teaching in the British and the American contexts.

Echoing American and English practices, Knight adopted the Beaux-Arts system at the Auckland School. This was proudly advertised in School prospectuses:

The training in design is based upon the world-famous system adopted by the École des Beaux Arts at Paris, which has been followed by Liverpool, Manchester, and London University Schools of Architecture with such 
distinguished success. It is also the system operative at the Architectural Association School in London and most of the American Universities (Prospectus 1931: 6).

The School of Architecture was established as a part of the developing Auckland University College, which was undergoing an intensive expansion to meet New Zealand's needs for a better, more systematic education. As a result, and in keeping with the British and American precedents, in contrast to the seemingly laissez-fair atmosphere of the École's ateliers, where students progressed at their own pace, studio design instruction was integrated with the university lecture and class systems. ${ }^{1}$

A question logically follows: Why was the Beaux-Arts method such a fitting model for development of tertiary-level architectural curricula? Discussing Beaux-Arts influences on the architectural profession in the United States, Joan Draper (1977) formed some insightful conclusions, and ones that are also relevant to the British and New Zealand experience. The standardisation of education following the Beaux-Arts model offered solutions to two major problems. First, the establishment of systematic rules helped overcome the rampant pluralism of nineteenth-century architectural styles. The French school developed a precisely defined, universal formula of historic architectural styles and a rational method for applying it. Furthermore, the Beaux-Arts system helped the development of specific professional abilities which would differentiate architects from other professionals of the construction industry. This contributed to the emergence of a specific, standardised approach to architectural design and, officially supported and acknowledged by the public, institutionalised education therefore played an important role in the professionalisation of architecture.

\section{"Architecture Confirmed History": The Beaux-Arts and the Importance of History}

Beaux-Arts architects approached the design process through a scholarly comprehension of the past. Their practice was heavily influenced by historicism. Challenging the older Universalist conception, the historicist notions of individuality and development altered the way humans perceived history (Reynolds 1999). The historicist thinkers expressed the idea, today a default for historical scholarship, that each historical phenomenon-whether a person, an event, or a complex political structure such as a state-was unique, different from others, and shaped by a specific set of conditions. Maintaining that the present was a part of the historical stream of development, humans started conceiving of culture historically.

Architecture was traditionally deemed to be a product of "high" culture par excellence. Christchurch architect Richard Harman vividly illustrated the significance of architecture in an address given to the New Zealand Society of Artists in 1934. He stressed that the "people of the past were judged by their architecture and people of the future would judge those of to-day in the same way" (Architecture and History" 1934: 12). Architecture was an integral part of civilisation. "Races without architecture were called barbarians, but those who built were held to be civilised. Architecture confirmed history ..." (“Architecture and History" 1934: 12).

The intellectual climate of historicism contributed to the prestige of historical study. Gwendolyn Wright (1990) notes that history courses legitimised 
professional training in architecture. According to Wright, professors of architecture at universities maintained that the history curriculum lifted their programmes above the technical schools where they were often first located: "History gave them autonomy and legitimacy within the academic setting" (1990: 17). Architects set off to examine the architectural production of the past, taking into consideration the wider, sociocultural background of any particular period. Students were encouraged to study the past not in the positivistic way of an archaeologist, but to understand the complex circumstances significant for the progress of human culture and their influence on forms and ornaments of architecture. The educated-and well-argued-choice of historic styles, dependent upon authoritatively generated precedents, resulted in a clearly identifiable model for architecture that was highly regarded throughout the Western world.

The belief in the relevance of the study of the past was deeply rooted in New Zealand architecture. Addressing the members of the Auckland Architectural Students' Association, the renowned architect William Gummer articulated this belief in a speech to Auckland architects in 1915. Gummer stressed that the purpose of historical study was comprehension, not the reproduction of "the structures of other peoples in other lands" (1915: 294). In the same year, Dunedin architect Leslie Coombs, in his lesson to architectural students, stressed that modern architecture should be in accordance with modern civilisation. And since:

... our civilization has developed from the experience of the past so our architecture should reasonably be expected to develop. Therefore study the history of architecture and the forms that were designed by the men who came before us, and make full use of the ideas. I say make use of the ideas, I do not say copy blindly the works (Coombs 1915: 199).

\section{The Teaching of History and Theory at the Auckland School of Architecture}

The degree structure at the Auckland School of Architecture remained largely unchanged for a period of 34 years, until 1961. Revolving around the thesis development, the fifth and final year allowed great freedom. In contrast, the teaching programme of the first four years demonstrated strong Beaux-Arts influences. For example, the fourth-year examination involved a typical esquisse-type Beaux-Arts test. The students had five days to develop a design solution for the programme to which they were introduced on the first day. An initial design concept had to be presented by the end of the first day. It could be further developed during the following four days, but the final design could not deviate from the original sketch "in its main line of compositions" (Prospectus 1948: 39).

The French tradition and importance placed on historical study in institutionalised education were even more evident in the first three years. The study of the architectural past was divided into three individual courses, taught from first- to third-year level. ${ }^{2}$ Theory of Architectural Design was offered to secondand third-year students. ${ }^{3}$ Architectural history directly informed the first-year Freehand Drawing paper. In the first part of the paper, the students were drawing the motifs of architectural ornaments from the cast, and, in the second, from memory. Descriptive Geometry and Sciagraphy offered in the second year included study of the "Ionic volute" and "geometry as a basis of ornamentation" 
(Prospectus 1948: 38). While the study of history and theory was important in the conceptual shaping of the undergraduate programme, it did not dominate over the timetable of lectures in comparison with the hours allocated to other courses (see Fig. 2). For example, in comparison to Structural Mechanics, where the students had five hours per week in the second year, every individual history and theory paper was taught one hour weekly, at all levels of study.
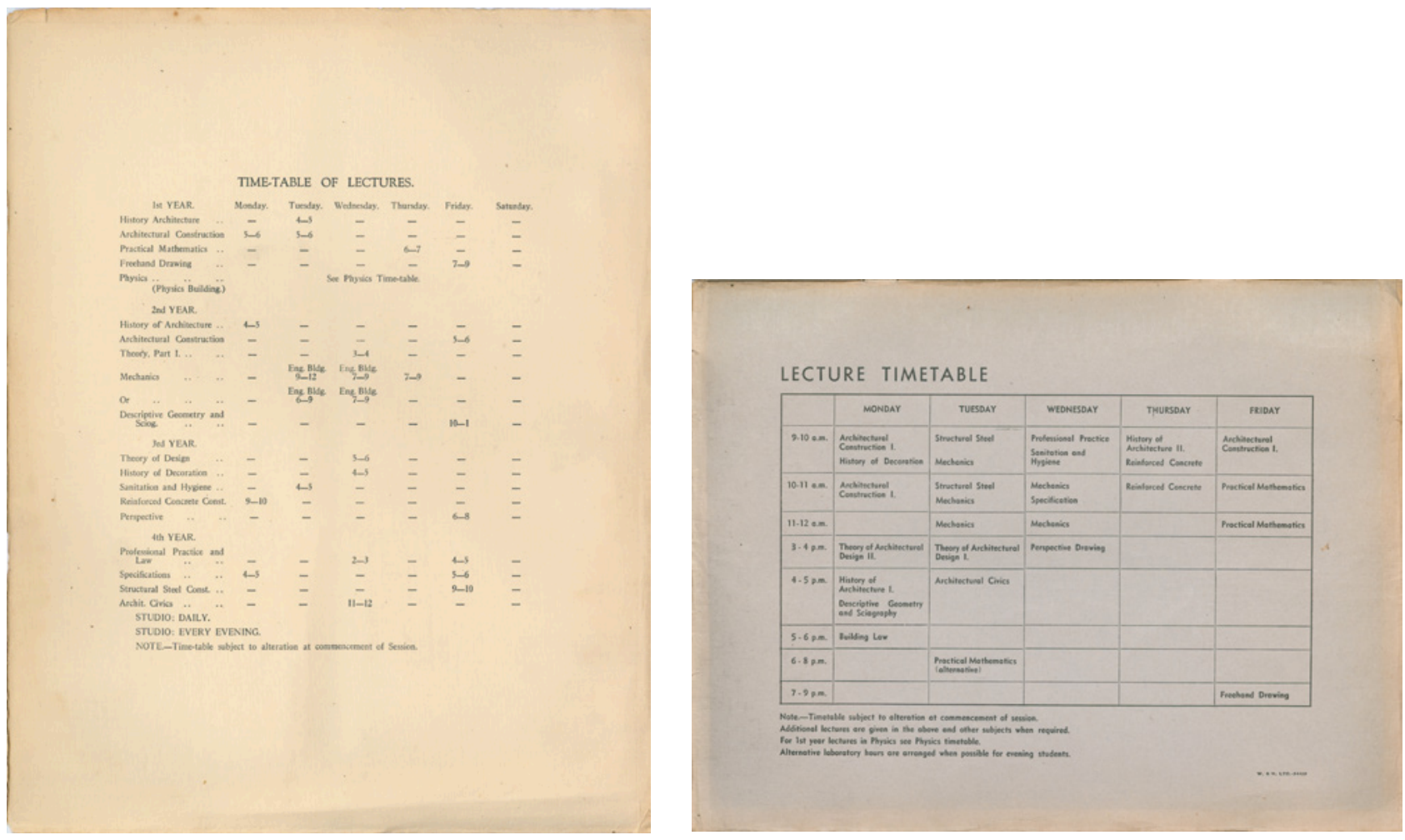

Fig. 2 Timetable of lectures: 1931 (a), 1944 (b). [Prospectus (Auckland: Auckland School of Architecture, $1931 ; 1944)]$
The place that history and theory courses held in the School curriculum is relatively clear. But who was behind them? Who were the people teaching history and theory at the Auckland School? The annual prospectuses regularly included a list of staff members. Interestingly, though it is possible to learn who was teaching subjects such as Architectural Construction, Physics, or Professional Practice and Law-and in what capacity-there is no official record of the history and theory lecturers. For some reason it was deemed unnecessary to record this information separately. It is well known that Knight was teaching architectural history for many years-his carefully prepared lecture notes, kept in the Architecture Archive at the University of Auckland, illustrate his enthusiasm for the subject. Additional information can be found in the passing comments in the "Annual Letters", written by Knight and included in the School prospectuses. For example, an Annual Letter from 1938 noted the contributions of Arthur Marshall, who was teaching construction and history to the second year. Imric Porsolt, a Hungarian who trained at Prague, was employed in 1950. Julia Gatley (2017) noted that Porsolt played an important role in the modernisation of history and theory teaching at the School: "He invigorated this subject area with interests that extended to modernism and also the applied arts" (50-51).

Finally, what tools did aspiring young architects have at their disposal for the exploration of professional principles validated and legitimised by centuries of 
experience? What were the official sources for the study of architectural history and theory? The School prospectuses also included lists of the titles the students were expected to read for different courses. Regardless of the individual preferences of the teachers, the officially recommended bibliography records the dominant attitude of the Auckland School. The reading lists published between 1927 and 1969 documented three phases of the Beaux-Arts influence on history and theory teaching at the Auckland School: predominance, from 1927 to 1947; transition, from 1948 to 1958; and then decline, from 1958 to 1969.

\section{7-1947}

As noted earlier, the prevalence of Beaux-Arts influences was initially advertised proudly on the first page in the School prospectuses. However, although no significant changes were made to the curriculum in 1940, the paragraph praising the "world-famous" French system was excluded from the prospectus documents from that time. The paragraph was omitted following Knight's (1937) return from his visit to approximately 40 architectural schools in the United States and the United Kingdom. In the 1938 "Annual Letter", Knight expressed his intention to make "many improvements" to the School curriculum as a result of the tour (Annual Letter 1938). The outbreak of the Second World War and its aftermath interfered with the realisation of his plans. Though there was awareness that Beaux-Arts methods were internationally perceived as outdated, the texts recommended for students studying architectural history and theory remained the same.
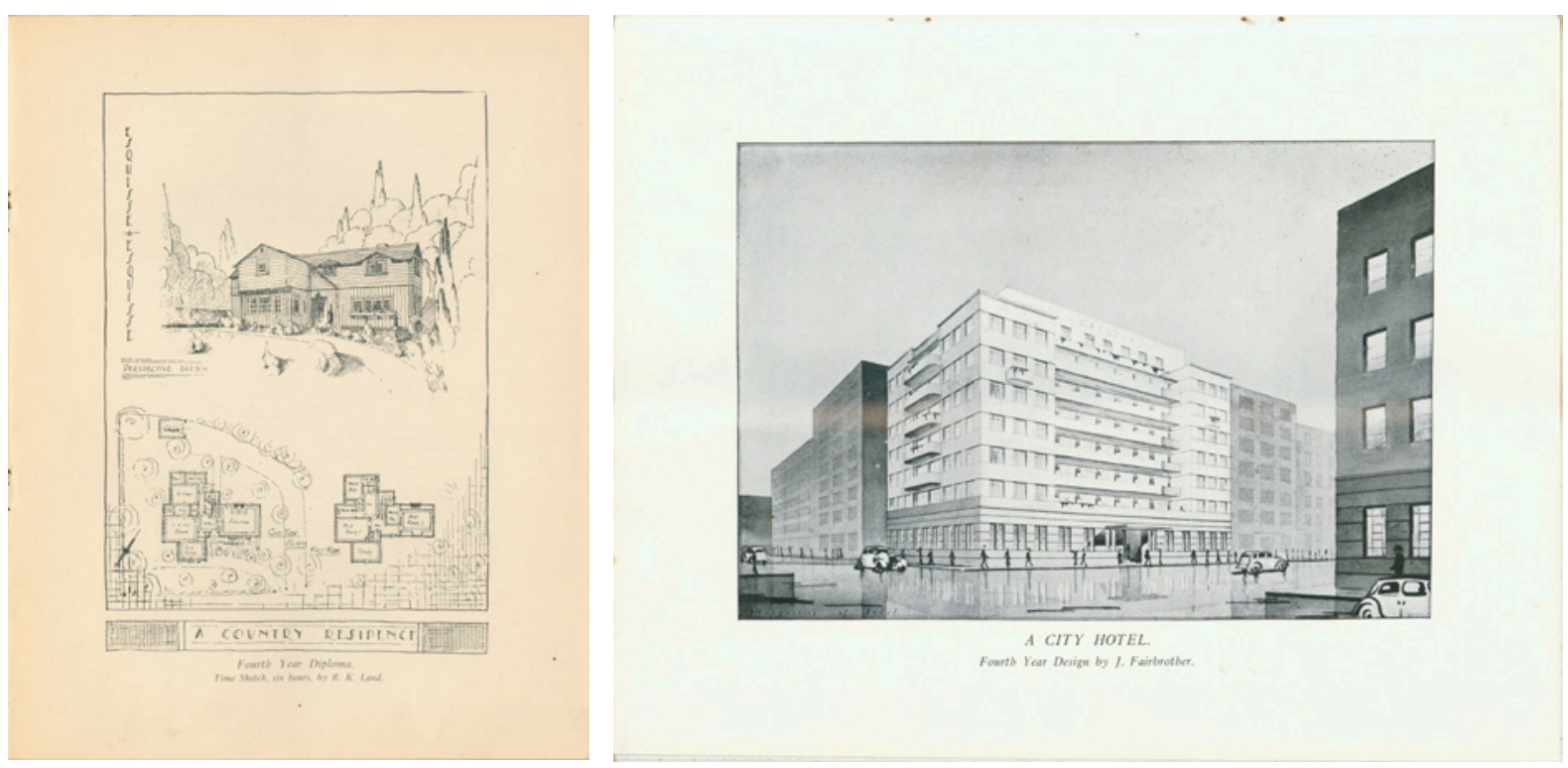

Fig. 3 A country residence: Fourthyear diploma time sketch, six hours, by R. Keith Land. [Prospectus (Auckland: Auckland School of Architecture, 1932)]

Fig. 4 A city hotel: Fourth-year design by J. Fairbrother. [Prospectus (Auckland: Auckland School of Architecture, 1938)]
There was a growing dichotomy between the recommended reading and the most successful student designs, which were also included in the School prospectuses in these years (see Fig. 4). The design solutions gradually transformed from the traditional eclectic historical approach of the late 1920s, to pristine, ornament-free façades from the mid-1930s onward, as students were increasingly influenced by modernist aesthetics. The strict symmetry of the Beaux-Arts planning methodology remained in place for the designs for public buildings, while more freedom was apparent in the planning of residential structures, such as a design for a country residence from 1932 (see Fig. 3). ${ }^{4}$ The shift in students' 
designs coincided with the broader changes New Zealand architecture was going through at that time. Publications, immigrants, architects returning from overseas, and projects by the Department of Housing Construction significantly contributed to the dissemination of modernist ideas in the late 1930s and early 1940s (Clark \& Walker 2000; Gatley 2008). The dichotomy was a result of the contrast in the curriculum itself, which, in turn, reflected the broader professional struggles of that period: architectural art or architectural science; historicist eclecticism or modernism? On one hand, history and theory courses drew lessons from the past, and in the spirit of Beaux-Arts tradition stressed the importance of ornament, preaching an art of architecture. On the other, courses such as Reinforced Concrete Construction or Sanitation and Hygiene were primarily focused on the future, relying on contemporary science and cutting-edge technologies. A similar pattern had developed at the Liverpool School of Architecture a decade earlier (Crouch 2002; Richmond 2001; Sharples, Powers, \& Shippbottom 1996). Alongside historicist projects, Art Deco and modernist influences increased from the second half of the 1920s. However, though the history of the Liverpool School is a widely researched topic, history and theory courses have not been studied individually so far. Therefore, it is not possible to claim that a similar discord between the teaching of history and theory and student designs existed at the Liverpool School in this period-this can only be assumed.

What was the teaching of history and theory like at the Auckland School of Architecture? In the first two history courses, students learnt about the development of architecture from Ancient History to the modern period. In the historicist tradition, rather than discussing the architectural forms as an abstract, aesthetic category, students were expected to obtain "a general knowledge of the history of nations with reference to its influence upon architecture" (Prospectus 1927: 13). The first-year courses surveyed Egyptian, Assyrian, Persian, Greek, Roman, Byzantine, Early Christian, Romanesque, and Gothic architecture. The second-year paper focused on Renaissance architecture in Italy, France, and England. It also introduced modern architecture: "The tendency in modern design" was explored with regard to "the influence and value of ancient architecture" and "its effect in England, America, and the colonies" (Prospectus 1927: 14). This was "modern" architecture as in contemporary, or of its time, rather than of the Modern Movement.

The reading lists for both courses consisted of the conservative classic texts of architectural history (see Fig. 5). The first-year students were to study from three canonical texts-the latest edition of Sir Banister Fletcher's famous A History of Architecture (1898); History of Architecture (1909) by Alfred D. F. Hamlin, the esteemed American architectural historian and professor at Columbia University; and William James Anderson and Richard Phené Spiers' The Architecture of Greece and Rome (1902). Fletcher's 1898 History remained a recommended text for longer than any other. In 1968, after 41 years, it was the last of the 1927 titles to be removed from the history reading list. The sources for the second-year exploration of tendencies in "modern design" remain unclear-for 21 years the official reading lists for the second-year history paper consisted solely of traditionalist titles on the Renaissance (Anderson 1898; Blomfield 1900; Gromort 1922; Ward 1911).

The content of the third-year history paper clearly demonstrated the School's affiliation with the Beaux-Arts system. It covered architectural history from early Egyptian to late Renaissance, "with special attention to architectural ornament 
Fig. 5 List of recommended titles, 1931. [Prospectus (Auckland: Auckland School of Architecture, 1931)]

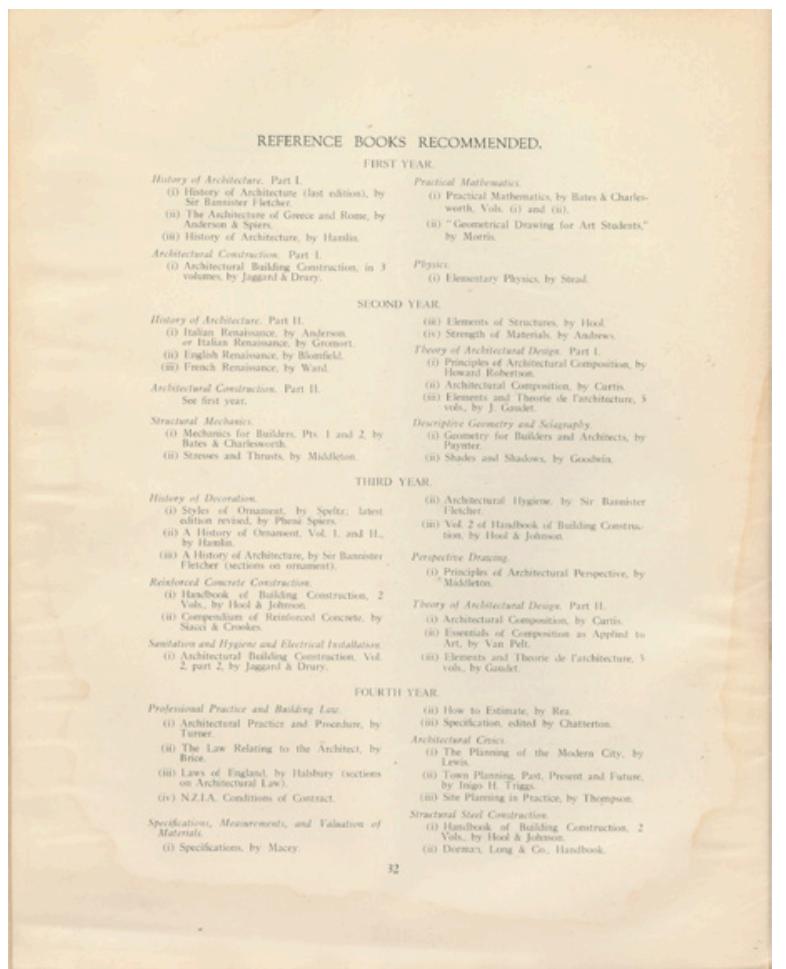

of each period" (Prospectus 1927: 14). Students also learnt about "sculpture, painting, ceramics and other methods practiced for decorative purposes" (Prospectus 1927: 14). Stressing the relevance of ornament and decoration in the best BeauxArts manner, the third-year paper strongly encouraged the discussion of architecture as an artistic category. The name of the paper itself was changed to History of Decoration in 1931. It was returned to History of Architecture, Part III almost a quarter of the century later, in 1955. Interestingly, the same year the name of the paper was first altered, "tendencies in modern decoration" (Prospectus 1931: 19) were added to the scope of the study, clearly showing the important place ornament held in the School's design methodology.

Students were encouraged to read about architectural ornament in the traditional titles-the extensive Styles of Ornament (1906), by the German author Alexander Speltz; the two influential volumes by Alfred Hamlin (1916); and the sections from Fletcher's History (1898). The third-year history paper was the most progressive of the three. In 1939 it was the first paper to include a book by a female author-Art Through the Ages (1936 [1926]), by the distinguished American art historian, Helen Gardner. ${ }^{5}$ Furthermore, in 1943, Art and Industry (1934) by Herbert Read and Nikolaus Pevsner's Pioneers of Modern Design (1936) introduced the modernist perspective in the third-year history curriculum.

Heavily influenced by the Beaux-Arts design methodology, the first-year theory paper focused on the general principles of composition, proportion, scale, and unity. The students were instructed in the laws of contrast, composition of masses, and character in design. Particular emphasis was placed on the "composition of plan, relation between plan, elevation and section" (Prospectus 1927: 17). Then, in the second year, planning was explored in greater detail. Special attention was given to the form of masses, wall treatment, and types of façades. 
For a period of 20 years, the students' understanding of architectural theory was developed-at least, officially-under the influence of the seminal works from the Beaux-Arts tradition. Principles of Architectural Composition (1924) by Howard Robertson was the first title on the list. Robertson accepted modernist ideas during the course of his career and in this very book raised the question of the appropriate architectural expression for modern buildings. However, when first published in 1924, the title considered the problems of unity, scale, composition, and architectural character from a Beaux-Arts perspective. A memento of French design methods in architectural education, for 40 years Robertson's Principles (1924) remained the official reference for theory courses at the Auckland School.

Students were also encouraged to read more traditional titles, such as Theory and Elements of Architecture (1926) by Atkinson and Bagenal, as well as the famous Éléments (1910) by the distinguished Beaux-Arts Professor Julien Gaudet. Finally, Architectural Composition (1923) by the American architect Nathaniel Curtis, the well-known survey examining the principles and practical applications of scale, balance, proportion, and symmetry, was included in 1928, and would remain on the list until 1965. The list of references for the second year of Theory of Architectural Design did not differ significantly from the first. It included the classic Beaux-Arts references-Gaudet's Éléments (1910), along with two titles on architectural composition by the American authors Curtis (1923) and John Van Pelt (1930).

\section{8-1958}

Reflecting the shifting-and conflicting-attitudes of the period, the reading lists for the history and theory courses changed in 1948. Though the BeauxArts titles-and influences-remained, from this year forward, a modernising tendency gradually gained in strength (McCarthy 2010). The change in history and theory teaching in 1948 followed a very particular series of events, outlined by Gatley (2017) in her centennial chapter on the post-World War II years at the Auckland School. In 1946, a group of second-year architectural students prepared a manifesto titled On the Necessity of Architecture and published the first issue of a magazine, Planning (Gatley 2010). The group consisted of young men and women, who were knowledgeable about modernism and increasingly disgruntled with the standard of education they were receiving. The next year saw student displeasure with the School's decision to appoint Charles Light, a conservative Beaux-Arts acolyte, for the Chair of Architecture in the area of design (Gatley 2017). Some would have preferred the appointment of another of the applicants, Ernst Plischke, an Austrian émigré and a well-known modernist architect who had arrived in New Zealand in 1939.

The situation intensified in 1948, when the Architectural Students' Society organised an Extraordinary Meeting which culminated in a vote of no confidence in the School's studio programme (Gatley 2017). The students wrote a report on the functioning of the School and submitted it to the College Council, demanding change. Among other issues, they complained about the extent to which the history and theory courses focused on past architectural styles. Instead, they wanted to learn about current architectural developments, and, more specifically, about modernism. Their vision for a restructured Bachelor of Architecture 
included a revised history course, one surveying the period from the industrial revolution to the Modern Movement. The School rejected the majority of the student suggestions. The official response regarding the history and theory teaching was uncompromising:

The treatment of History and Theory in this School as to both subject matter and method is in general accordance with that in University Schools of Architecture in England. The statutes cover the development of history and theory from ancient times to the present day. The subjects are not, as some students believe they should be, devoted in the main to recent work (as in the case of Studio work) but endeavour to promote a knowledge of the development of the cultures of different races concerned in the evolution of European civilization. In our view this approach is necessary to an understanding of present day architecture. ${ }^{6}$

However, in spite of the resolute official attitude of the School, changes were introduced to the history and theory programme (see Fig. 6). The descriptions of the courses remained the same, but the 1948 reading lists demonstrate a response to student requests. The theory courses were significantly altered. In the first-year paper, the modernist bible Towards a New Architecture (Le Corbusier 1927) and the influential Space, Time and Architecture (Giedion 1941), replaced Curtis' and Gaudet's classic references. The same year, a number of lesser known progressive titles were introduced to the first-year reading list (Faulkner, Ziegfeld, \& Hill ca. 1949; Leathart 1940; Yorke \& Penn 1939). The Beaux-Arts holy trinity of Curtis (1923), Van Pelt (1930), and Gaudet (1910) was off the list for the second-year theory paper, never to return; from 1949, the reference list was completely modernist.

Fig. 6 List of recommended titles, 1948. [Prospectus (Auckland: Auckland School of Architecture, 1948)]

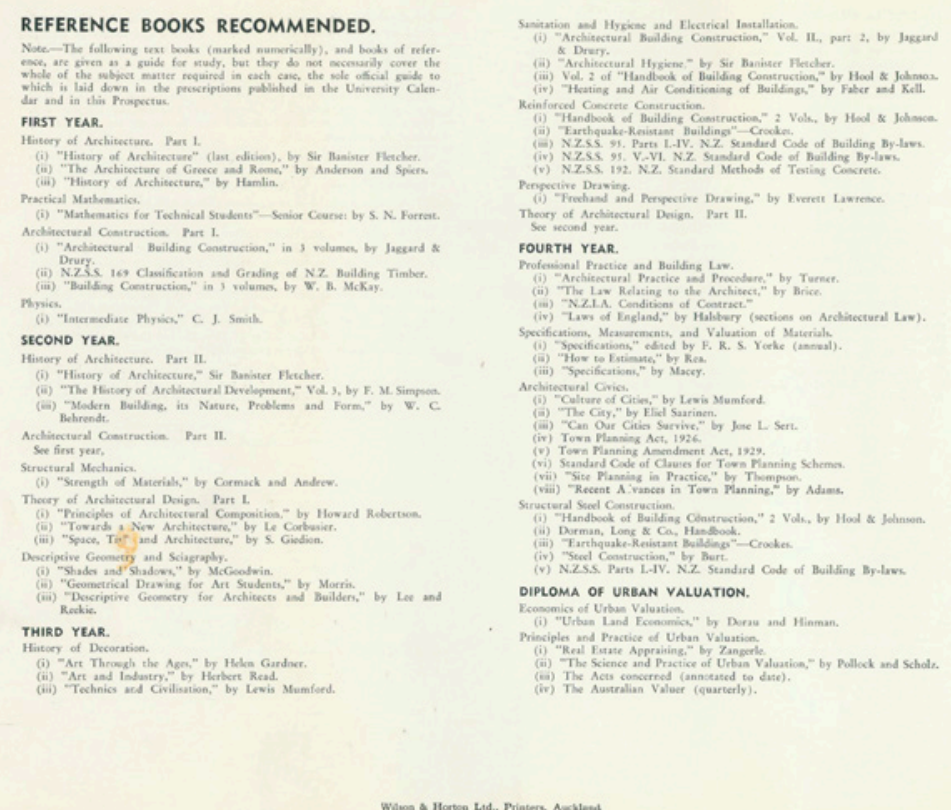

43 
In comparison, the teaching of history was transformed at a slower pace. For example, the reading list for the first-year history of architecture paper changed for the first-and only-time in 1953, when An Outline of European Architecture (Pevsner 1948) was included. The year 1948 brought the first modernist title to second-year history-Modern Building (Behrendt 1937). Reflecting the dualism of Beaux-Arts and modernist approaches, two quite different books were added to second-year history in 1950-Pevsner's An Outline (1948) and Hamlin's History of Architecture (1909). The third-year history paper changed most drastically. Technics and Civilization (Mumford 2010) was added in 1948, followed by a number of other modernist and interdisciplinary titles in subsequent years (Childe 1964; Pevsner 1948; Summerson 1949). Interestingly, the list for the thirdyear history paper was excluded from the 1957 Prospectus, with an explanation that "the field of study in this subject is too wide to be covered by a list of some half dozen books" (Prospectus 1957: 14).

From this point on, the teaching of history and theory at the Auckland School started catching up with international practices. However, unlike other courses, it remained completely exclusive of certain topics in the period covered by this article. For example, as a response to local needs, the study of earthquake-resistant buildings and the official New Zealand building regulations was introduced in the paper on reinforced concrete construction as early as 1941 (Prospectus 1941: 14). Furthermore, the post-World War II period witnessed growing demands and efforts to develop a specific, New Zealand architecture. The result was a diverse architectural production since the late 1940s, with a distinguished current of New Zealand modernism (Gatley 2010). In contrast, as far as the history and theory courses were concerned, New Zealand's own architectural past did not exist. References exploring the local architectural achievements were not-at least officially-included in the period covered by this article.

\section{8-1969}

From 1958, the Prospectus no longer presented the reference lists by courses and year levels. Instead, it consolidated them into the different areas of study (see Fig. 7). Traditional titles, such as Fletcher's History (1898) and The Art of Architecture (1938) by Richardson and Corfiato were still recommended. However, the following 10 years saw a gradual shift from general overviews of architectural history towards more specific research topics. Outdated titles like Ward's 1911 book on the French Renaissance and Hamlin's History (1909) were replaced (in 1958 and 1961 respectively) with more recent studies (Blunt 1999; Frankfort 1954; Hitchcock 1968). The 1960s prospectuses illustrated a humanist interest in broadening the understanding of architecture. The teaching of history was enriched with titles from other disciplines, most notably by major studies from the discipline of art history (Burckhardt 1945; Gombrich 1995; Wittkower 1959).

The merged theory list highlighted the contrast between the conservative BeauxArts tradition and modernising efforts. Contrary to the generally progressive attitudes of this period, The Architecture of Humanism (1914) by Geoffrey Scott was added in 1958. In this famous early twentieth-century treatise, Scott attempted to formulate the main principles of architectural classicism. In contrast, the introduction of titles such as Contemporary Structure in Architecture (Michaels 1950) attests to a shift to a more scientific design methodology. Similarly to the 
Fig. 7 List of recommended titles, 1958. [Prospectus (Auckland: Auckland School of Architecture, 1958)]

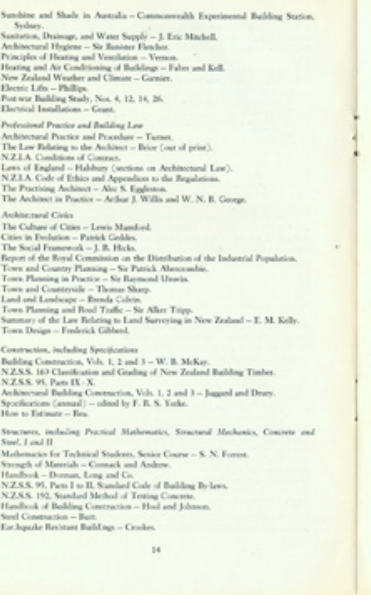

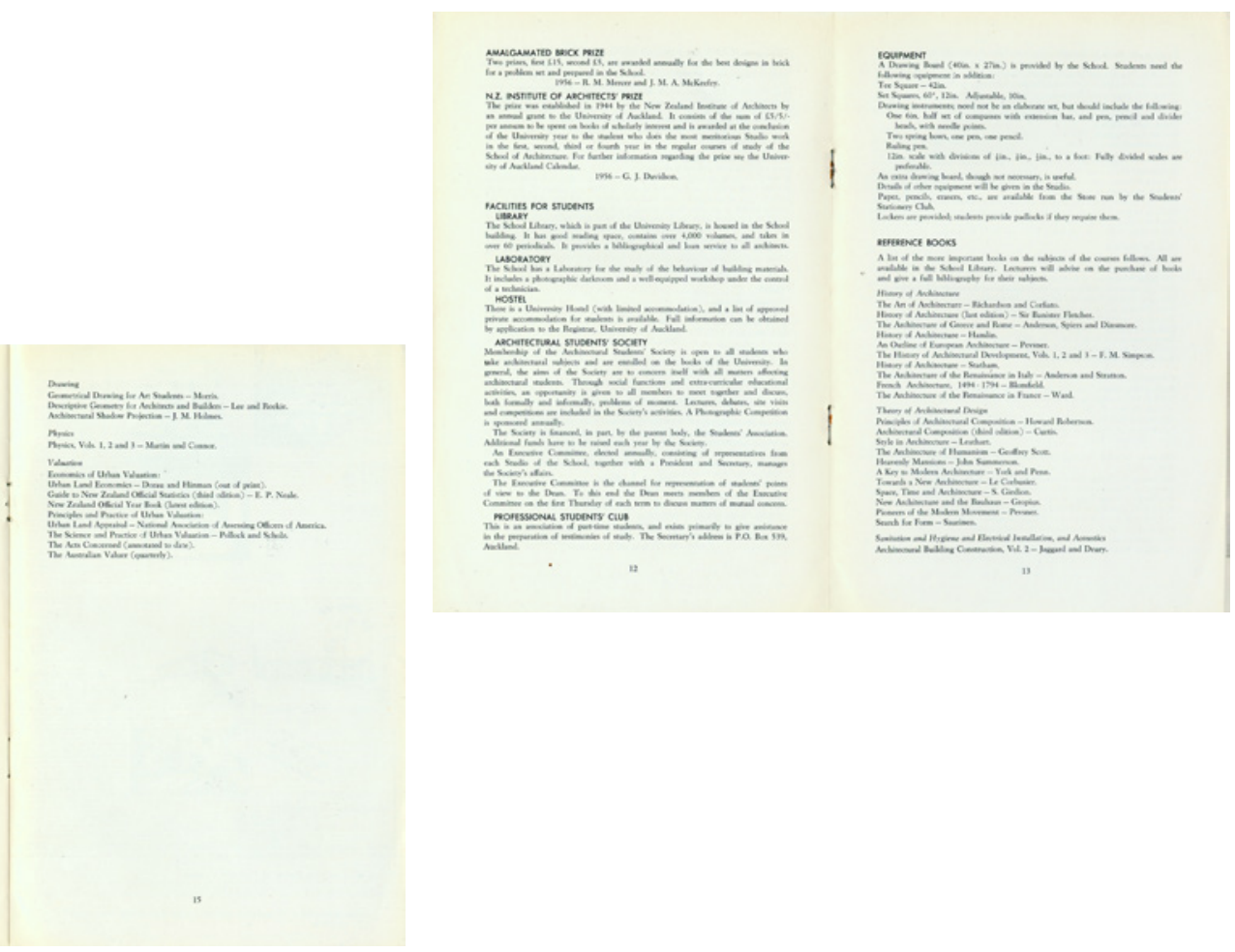

history courses, a number of books added to the theory reading list during the 1960s reflected the tendency to explore and experience architecture from an interdisciplinary perspective (Arnheim 2004; Kepes 1944; Rasmussen 1964).

Coinciding with the retirement of older staff members-starting with Professor Knight in 1958 - the sixth decade of the twentieth century witnessed the end of Beaux-Arts influences at the Auckland School of Architecture. As illustrated by the best student work published in the prospectuses, Beaux-Arts aesthetics were long forgotten by this time. However, French academic teaching and design methods persisted. The final countdown for the Beaux-Arts was signalled in 1961, when the five-day esquisse-type test was deleted from the fourth-year studio (Gatley 2017). The same year significant changes were made to the history curriculum. Starting with 1961, architectural history at the School was divided into two courses, taught at the first- and the third-year levels.

In the following years, the titles in the Beaux-Arts tradition were gradually excluded from the theory teaching. Curtis' Architectural Composition (1923) was removed in 1965, and Robertson's Principles of Architectural Composition (1924) and Scott's The Architecture of Humanism (1914) were recommended for the last time in 1966. In 1967, 40 years after the Auckland School of Architecture printed its first Prospectus, the reading lists excluded all of the major works in the tradition of the Beaux-Arts. However, the echoes of the Beaux-Arts principles lingered for two more years. The sharp contrast between the contemporary design methodology and traditionalist principles remained apparent in the description of Theory of Architectural Design I. The functionalist approach to architecture was merged with a humanist "man as measure" ideal, and taught alongside the character-defining Beaux-Arts qualities of unity, rhythm, and scale (Prospectus 1969: 11). The 1970 Prospectus marked the end of an era. Completely redesigned, it was the first booklet devoid of even a faintest reference to the École des Beaux-Arts. 


\section{Conclusion}

To return to Mauriac's words, the students at the Auckland School of Architecture were re-reading the seminal titles of the Beaux-Arts tradition in the period covered by this article. History and theory courses remained the main carriers of Beaux-Arts influences, informing design-related courses for decades. However, they were in contrast with the actual student designs, and essentially detached from the practically oriented courses. The most successful student work published in the annual School prospectuses demonstrates that the aesthetics of the historicist eclecticism were abandoned from the mid-1930s. The transition from traditionalist to modernist architectural forms was gradual, similar to that at the Liverpool School. Typically for the remoteness of New Zealand, it occurred with a decennial delay-since the mid-1930s. Courses such as Structural Mechanics, Reinforced Concrete Construction, and Professional Practice and Building Law were up to date with the most recent findings and closely related to practice in New Zealand. After all, architecture remains a niche profession in New Zealand, and the School attempts to prepare its students for it. The student designs and the majority of the curriculum show that, in general, the training at the Auckland School did not lag behind architectural practice in New Zealand.

Nonetheless, the prospectuses printed between 1927 and 1969 record the persisting Beaux-Arts practices at the Auckland School. The modernising aspirations of the late 1930s were interrupted by the outbreak of the Second World War and its consequences. In the pre-war period, following his visit to various architectural schools in the United States and the United Kingdom, Knight announced that there would be curriculum change and thus showed awareness that the teaching at the Auckland School needed to be brought up to date with international practices. But in the immediate post-war years, the leadership at the School took a rather conservative stand. They responded slowly to the mid-century modernising demands of the majority of students and some of the staff. The drastic increase of student numbers after the war made securing the sufficient funds for additional staff and adequate teaching spaces a priority. Under the circumstances, revaluation of the curriculum was considered less pressing. Perhaps the most telling choice made in the years following the war was the decision to employ Charles Light as the Professor of Design in 1947. The decision to hire a conservative Beaux-Arts acolyte, instead of a more progressive architect, should be seen both as a symptom of broader circumstances responsible for, and as a contributing factor towards, the slower modernisation of the Auckland School.

Although 1948 marked a beginning of the modernisation of the history and theory curriculum, the canonical Beaux-Arts texts continued-at least officially-to serve as valid references for two more decades. Consequently, the teaching of history and theory became anachronistic. The failure to adapt in a timely manner to the altered circumstances of the post-war period caused dissatisfaction and had far-reaching consequences. This can be seen as the moment when history and theory courses acquired the status they still have among students, who often struggle to comprehend their relevance to their primary aspirations in contemporary design.

However faint, the Beaux-Arts rhetoric was still present at the Auckland School of Architecture as late as 1969. Did this mean the School was producing BeauxArts architects in the late 1960s? Certainly not. However, it might have meant 
two things. First, that there was someone in a leadership position convinced of the relevance of the French experience for contemporary architectural education. Furthermore, the ideas the students were reading about-the principles of composition, symmetry, proportion, and the idea of an architectural art-must, unavoidably, have left some traces. It would be interesting to re-examine the works of the prominent, progressive New Zealand architects who graduated in the 1950s and 1960s. Future scholarship might yet determine that it contains echoes off their Beaux-Arts influenced education.

ENDNOTES

${ }^{1}$ The system of student-run ateliers did exist in Auckland, since the Architectural Students Association had established it in 1914 (Bassett 2011).

${ }^{2}$ Annual prospectuses for the Auckland School of Architecture published between 1927 and 1969.

${ }^{3}$ Between 1927 and 1931, theory was taught in the third and the fourth years. From 1931 onward, the theory papers were introduced earlier, in the second and the third years.

${ }^{4}$ Student design published in the 1932 Prospectus.

${ }^{5}$ Influencing art education in the United States, Gardner's book remained a standard textbook at the American schools and universities for decades (Kader 2000).

${ }^{6}$ A typed copy of the original "Report of the Faculty of Architecture", March 31, 1949. Auckland University College Council Minutes, 1949, Vol. 1, pp. 333-334. A copy is available at C. R. Knight Papers, Architecture Archive, the University of Auckland Library.

\section{REFERENCES}

Anderson, W. (1898). The architecture of the Renaissance in Italy: A general view for the use of students and others. London, New York: B.T. Batsford, Charles Scribner's Sons.

Anderson, W., \& Spiers, R. P. (1902). The architecture of Greece and Rome: A sketch of its historic development. London: Batsford.

Annual letter in Prospectus. (1938). Auckland: School of Architecture, University of New Zealand.

Anonym. (1934, June 11). Architecture and history: Development of an ancient architecture, Press, 7O(21187), 12.

Arnheim, R. (2004). Art and visual perception: A psychology of the creative eye. Berkeley: University of California Press.

Atkinson, R., \& Bagenal, H. (1926). Theory and elements of architecture. London: Ernest Benn.

Bassett, D. (2011). The BeauxArts method in New Zealand. In Christine McCarthy (Ed.), Good architecture should not be a plaything: New Zealand architecture in the 1920s (p. 20). Wellington: Centre for Building Performance Research, Victoria University of Wellington.

Behrendt, W. (1937). Modern building: Its nature, problems, and forms. New York: Harcourt, Brace and Co.

Blomfield, R. (1900). A short history of Renaissance architecture in England 1500-1800. London: George Bell and Sons.

Blunt, A. (1999). Art and architecture in France, 15001700. New Haven: Yale University Press.

Burckhardt, J. (1945). The civilization of the Renaissance in Italy. New York: Oxford University Press.

Childe, G. (1964). What happened in history. Harmondsworth: Penguin.

Clark, J., \& Walker, P. (2000). Looking for the local: Architecture and New Zealand modern. Wellington: Victoria University Press.

Coombs, L. (1915, August 1). A lesson on design to students of architecture. New Zealand Building Progress, 10(12), 399.

Crouch, C. (2002). Design culture in Liverpool 1880-1914: The origins of the Liverpoo/ School of Architecture. Liverpool: Liverpool University Press.

Curtis, N. (1923). Architectural composition. Cleveland: J. H. Jansen.

Draper, J. (1977). The Ecole des Beaux-Arts and the architectural profession in the United States: The case of John Galen Howard. In Spiro Kostof (Ed.), The architect: Chapters in the history of the profession (pp. 209-238). New York: Oxford University Press.

Drexler, A. (1977). The architecture of the Ecole des Beaux-Arts [Exhibition catalogue]. London: Secker \& Warburg.

Egbert, D., \& Van Zanten, D. (ca. 1980). The beaux-arts tradition in French architecture. Princeton: Princeton University Press.

Faulkner, R., Ziegfeld, E., \& Hill, G. (ca. 1949). Art today: An introduction to the fine and functional arts. New York: H. Holt.

Fletcher, B. (1898). A history of architecture on the comparative method: For students, craftsmen and amateurs. London: Batsford.

Frankfort, H. (1954). The art and architecture of the ancient orient. Harmondsworth: Penguin.

Gardner, H. (1936 [1926]). Art through the ages. Belmont: Thomson, Wadsworth.

Gatley, J. (Ed.). (2008). Long live the modern: New Zealand's new architecture, 1904-1984. Auckland: Auckland University Press.

Gatley, J. (2010). Who was who in the Group? In J. Gatley (Ed.), Group Architects: Towards a New Zealand architecture (pp. 29-33). Auckland: Auckland University Press.

Gatley, J. (2017). After Knight comes Light (and Toy): The modernising years. In J. Gatley \& L. Treep (Eds.), The Auckland School: 100 years of architecture 
and planning (pp. 40-74).

Auckland: School of Architecture and Planning, University of Auckland.

Gaudet, G. (1910). Éléments et théorie de l'architecture. Paris: Librairie de la construction modern.

Giedion, S. (1941). Space, time and architecture: The growth of a new tradition. Cambridge: Harvard University Press.

Gombrich, E. (1995). The story of art. London: Phaidon Press.

Gromort, G. (1922). Italian

Renaissance architecture. London: John Tiranti.

Gummer, W. (1915, May 1). The study of architecture, New Zealand Building Progress, 10(9), 293-298.

Hamlin, A. D. F. (1909). History of architecture. New York: Green Longmans.

Hamlin, A. D. F. (1916). A history of ornament: Renaissance and modern. New York: The Century Co.

Hitchcock, H. R. (1968)

Architecture: 19th and 20th centuries. Harmondsworth: Penguin Books.

Kader, K. (2000). The bible of art history: Gardner's art through the ages, Studies in Art Education, 41(2), 164-177.

Kepes, G. (1944). Language of vision. Chicago: P. Theobald.

Knight, C. (1937). Architectural education in the British Empire: A report. Auckland University College Faculty of Architecture, Auckland.

Leathart, J. (1940). Style in architecture. London, Toronto: Thomas Nelson \& Sons.

Le Corbusier. (1927). Towards a new architecture. New York: Brewer, Warren \& Putnam. First published in French in 1923, under the title Vers une architecture.

Mauriac, F. (1959). Mémoires intérieurs. Paris: Flammarion.

McCarthy, C. (2010). The roaring forties: Reforming architectural education. In J. Gatley (Ed.), Group Architects: Towards a New Zealand architecture (pp. 29-33) Auckland: Auckland University Press.

McEwan, A. (1999). Learning by example: Architectural education in New Zealand before 1940. Fabrications: The Journal of the Society of Architectural Historians, Australia and New Zealand, 9, 1-16.

McEwan, A. (2001). An "American dream" in the "England of the Pacific": American influences on New Zealand architecture, 18401940 (Unpublished Thesis for the Degree of Doctor of Philosophy in Art History). University of Canterbury, Christchurch.

Michaels, L. (1950).

Contemporary structure in architecture. New York: Reinhold.

Mumford, L. (2010). Technics and civilization. Chicago: University of Chicago Press.

Noffsinger, J. P. (1955). The influence of the Ecole des BeauxArts on the architects of the United States [Doctoral thesis]. Washington, D.C., USA: The Catholic University of America Press.

Pevsner, N. (1936). Pioneers of modern design. London: Faber \& Faber.

Pevsner, N. (1948). An outline of European architecture. London: J. Murray.

Prospectus. (1927). Auckland: School of Architecture, University of New Zealand.

Prospectus. (1931). Auckland: School of Architecture, University of New Zealand.

Prospectus. (1941). Auckland: School of Architecture, University of New Zealand.

Prospectus. (1948). Auckland: School of Architecture, University of New Zealand.

Prospectus. (1957). Auckland: School of Architecture, University of New Zealand.

Prospectus. (1969). Auckland: School of Architecture, University of New Zealand.

Rasmussen, S. (1964).

Experiencing architecture.

London: Chapman \& Hall.

Read, H. (1934). Art and industry: The principles of industrial design. London: Faber and Faber.

Reynolds, A. (1999). What is historicism? International Studies in the Philosophy of Science, 13(3), 275-287.
Richardson, A., \& Corfiato, $\mathrm{H}$. (1938). The art of architecture. London: English University Press.

Richmond, P. (2001). Marketing modernisms: The architecture and influence of Charles Reilly. Liverpool: Liverpool University Press.

Robertson, H. (1924). The principles of architectural composition. London: Architectural Press.

Scott, G. (1914). The architecture of humanism: A study in the history of taste. Edinburgh: University Press.

Sharples, J., Powers, A., \& Shippbottom, M. (1996). Charles Reilly and the Liverpoo/ School of Architecture [Exhibition catalogue]. Liverpool: Liverpool University Press.

Speltz, A. (1906). Styles of ornament. New York: Grosset \& Dunlap.

Summerson, J. N. (1949).

Heavenly mansions: And other essays on architecture. London: Cresset.

Treep, L. (2017). "A school of architecture for the Dominion": The first years. In J. Gatley \&

L. Treep (Eds.), The Auckland School: 100 years of architecture and planning (pp. 14-39).

Auckland: School of Architecture and Planning, University of Auckland.

Van Pelt, J. (1930). The essentials of composition as applied to art. New York: The Macmillan Co.

Ward, W. H. (1911). The architecture of the Renaissance in France: A history of the evolution of the arts of building, decoration and garden design under classical influence from 1495 to 1830. London: Batsford.

Wittkower, R. (1959). Art and architecture in Italy, 1600-1750. Harmondsworth: Penguin.

Wright, G. (1990). History for architects. In G. Wright \& J. Parks (Eds.), The history of history in American schools of architecture, 1865-1975 (p. 17). New York: Temple Hoyne Buell Center for the Study of American Architecture.

Yorke, F. R. S., \& Penn, C. (1939).

A key to modern architecture. London, Glasgow: Blackie and Son. 